\title{
The Relationship between Internet Addiction, Internet Gaming and Anxiety among Medical Students in a Malaysian Public University during COVID-19 Pandemic
}

\author{
Nurazah Ismail ${ }^{1,2} \oplus$, Ahmad Izzat Tajjudin ${ }^{1}$, Hafiz Jaafar ${ }^{3}$, Nik Ruzyanei Nik Jaafar ${ }^{2,4} \oplus$, Azlin Baharudin ${ }^{2,4, *}$ \\ and Normala Ibrahim ${ }^{2,5}$ \\ 1 Psychiatry Unit, Department of Medicine, Faculty of Medicine and Health Sciences, Universiti Sains Islam \\ Malaysia, Nilai 71800, Malaysia; azah.ismail@usim.edu.my (N.I.); izzattajuddin@usim.edu.my (A.I.T.) \\ 2 Malaysian Society of Internet Addiction Prevention, Universiti Putra Malaysia (UPM), \\ Serdang 43400, Malaysia; ruzyanei@ppukm.ukm.edu.my (N.R.N.J.); normala_ib@upm.edu.my (N.I.) \\ 3 Public Health Unit, Department of Primary Health Care, Faculty of Medicine and Health Sciences, \\ Universiti Sains Islam Malaysia, Nilai 71800, Malaysia; dr.hafizjaafar@usim.edu.my \\ 4 Department of Psychiatry, Faculty of Medicine, Universiti Kebangsaan Malaysia Medical Centre, \\ Jalan Yaacob Latif, Kuala Lumpur 56000, Malaysia \\ 5 Department of Psychiatry, Faculty of Medicine and Health Sciences, Universiti Putra Malaysia (UPM), \\ Serdang 43400, Malaysia \\ * Correspondence: drazlin@ppukm.ukm.edu.my; Tel.: +60-3-91456142 or +60-3-91456143
}

Citation: Ismail, N.; Tajjudin, A.I.; Jaafar, H.; Nik Jaafar, N.R.; Baharudin, A.; Ibrahim, N. The Relationship between Internet Addiction, Internet Gaming and Anxiety among Medical Students in a Malaysian Public University during COVID-19 Pandemic. Int. J. Environ. Res. Public Health 2021, 18, 11870. https:// doi.org/10.3390/ijerph182211870

Academic Editors: Elisardo Becoña Iglesias and Paul B. Tchounwou

Received: 13 August 2021

Accepted: 3 November 2021

Published: 12 November 2021

Publisher's Note: MDPI stays neutral with regard to jurisdictional claims in published maps and institutional affiliations.

Copyright: (c) 2021 by the authors. Licensee MDPI, Basel, Switzerland. This article is an open access article distributed under the terms and conditions of the Creative Commons Attribution (CC BY) license (https:// creativecommons.org/licenses/by/ $4.0 /)$
Abstract: The internet has become an important medium for learning and communication during the COVID-19 pandemic, particularly for university students. Nevertheless, an increase in internet usage could predispose people to internet addiction (IA) and internet gaming (IG). Equally, there is concern that anxiety levels have increased during the pandemic. The aim of this study is to determine the prevalence of IA and IG, and their associations with anxiety among medical students during the pandemic. Data were collected during the second wave of the "Conditional Movement Control Order" (CMCO) in Malaysia between 12 November and 10 December 2020. A total of 237 students participated through proportionate stratified random sampling in this cross-sectional study. They completed a set of online questionnaires which consisted of a sociodemographic profile, the Malay version of the internet addiction test (MVIAT), the Malay version of the internet gaming disordershort form (IGDS9-SF) and the Malay version of the depression, anxiety and stress scale (DASS-21). The prevalence of IA and internet gaming disorder (IGD) were $83.5 \%$ and $2.5 \%$, respectively. A multiple logistic regression showed that those in pre-clinical years had a greater risk of anxiety than those in clinical years $[(\mathrm{AOR})=2.49, p$-value $0.01,95 \% \mathrm{CI}=1.22-5.07]$. In contrast, those who scored high on IA were protected against anxiety [AOR $=0.100, p$-value $0.03,95 \% \mathrm{CI}=0.01-0.76)]$. In conclusion, IA was highly prevalent during the COVID-19 pandemic and its high usage might serve as a protective factor against anxiety among the medical students in this study sample.

Keywords: internet addiction; internet gaming; medical students; anxiety; COVID-19

\section{Introduction}

The advent of a deadly virus, coronavirus virus disease 2019 (COVID-19), has had a profound impact on everyone. As a result of COVID-19's large-scale outbreak infection, the World Health Organization (WHO) declared the outbreak as a pandemic in March 2020 and required rapid and extensive measures to keep from the spreading of the disease. As soon as the disease transmission increased in March 2020, it prompted the government to implement a "Movement Control Order" (MCO) to curb the spreading of the virus. This was imposed in phases until it entered a recovery phase beginning on the 10th of June onwards [1]. Unfortunately, the country experienced a second wave of COVID-19 in October 2020, which led to the enforcement of the Conditional Movement Control Order 
(CMCO) with a tighter standard operation procedure (SOP) than the earlier recovery phase. The CMCO was extended until early December 2020 as Malaysia continued its fight against the pathogen and certain economic activities were allowed to function under strict SOPs [2].

During the COVID-19 pandemic, the internet has taken a more prominent role and became the most common means of learning, communication, and conveying information. This was also reflected by a high number of internet users in Malaysia as reported in the Internet Users Survey (IUS) by the Malaysian Communication and Multimedia Commission $(\mathrm{MCMC})$ in 2020, where $88.7 \%$ were internet users [3]. Students, particularly, were affected by the switch from the conventional face-to-face learning to virtual platforms. This could predispose them to internet-related problems such as internet addiction (IA) and internet gaming disorder (IGD) [4].

In a meta-analysis study from 31 countries, the global prevalence of IA before the pandemic was found to be around $6.0 \%$ [95\% CI 5.1-6.9], with the highest prevalence found in the Middle East at 10.9\% [95\% CI 5.4-6.3] and the lowest prevalence found in Northern and Western Europe at 2.6\% [95\% CI 1.0-4.1]. The prevalence of IA in Asian countries was high at $7.1 \%$ [5]. Among medical students, another meta-analysis showed that the pooled prevalence of IA pre-pandemic was 30.1\% [95\% CI 28.5-31.8\%], whereby the prevalence was $36.9 \%$ for Malaysia [6-8]. When compared between the global prevalence and studies conducted among medical students, the prevalence rate was six times higher than that of the general population, placing them among the vulnerable group.

For IG, it can be a temporary method for stress relief. However, it may become a disorder when the coping turns out to be maladaptive and subsequently leads to disruptions in major areas of functioning. The prevalence of internet gaming disorder (IGD) in European countries pre-pandemic varied from $1.2 \%$ to $5.0 \%$, compared to a higher range of prevalence among Asian countries, i.e., from $7.5 \%$ to $26.7 \%$ [9]. The local prevalence for IG is $18 \%$ [10]. A recent study on IGD among Malaysian undergraduates found that $52.8 \%$ of them scored high on a validated IGD scale [11]. The disparity across these figures in IA and IGD may be attributed to the use of different objective assessment tools and the heterogeneity of the sample population [12].

This pandemic has left significant psychological impacts such as insomnia, anxiety and depression [13-15] in addition to the direct effects of the virus itself [16]. Anxiety has been highly prevalent and affects various subpopulations differently depending on their risk profile $[17,18]$. The constant and ongoing stressors for medical students placed them among the vulnerable group attributed to social isolation, suspension of studies, impact of online learning and possibly limited clinical exposure [19].

A recent study conducted among Malaysian youth during the pandemic which examined the relationship between anxiety and IA, found that individuals with higher internet usage scored more in the anxiety inventory [20]. Therefore, this study aimed to determine the prevalence of internet usage and IG among medical students and whether they are linked to anxiety during the pandemic. Understanding these factors would provide insight for the university management and other stakeholders on adaptive strategies during pandemic times to facilitate medical students' learning and optimize care for their psychological wellbeing.

\section{Materials and Methods}

This is a cross-sectional study conducted among medical students in a Malaysian public university. The survey was opened to all medical students in the Islamic Science University of Malaysia (USIM) who had been using the internet for the past 12 months or more. Those who identified themselves as currently under psychiatric follow-up and/or in treatment were excluded from the study. A total of 250 students (from all academic years) were recruited through proportionate stratified random sampling as described in. The randomization was generated using a computer software. Those who consented to participate in the study were given a set of self-rated, pre-tested and validated questionnaires for internet addiction, internet gaming and anxiety using Google Form. This was due to 
the restricted movement during the COVID-19 pandemic in Malaysia. Respondents were required to fill out the sociodemographic questionnaire consisting of their information regarding age, gender, marital status, ethnicity, internet gaming characteristics and internet use patternFigure 1 [21]. The Malay version of the internet addiction test (MVIAT) is a self-reported questionnaire to measure the characteristic and behaviour patterns of internet usage including the functionality in major important areas [22]. The sensitivity and specificity were $63 \%$ and $61 \%$, respectively in the validated MVIAT. The Cronbach alpha was 0.91 [23,24]. The Malay version of the internet gaming disorder scale-short form (IGDS9-SF) was used to measure internet gaming behaviour and its severity [25]. The sensitivity and specificity were $98.0 \%$ and $91.9 \%$, respectively, in the validated Malay version $[26,27]$. The Cronbach alpha was 0.87 in the present study [28]. The Malay version of the depression, anxiety, stress scale-21 (DASS-21) was used as a screening tool for anxiety level in this study. The Cronbach alpha in the validated Malay version was 0.74 for anxiety [29]. Data collection was conducted during the second wave of the CMCO period between 12 November 2020 and 10 December 2020.

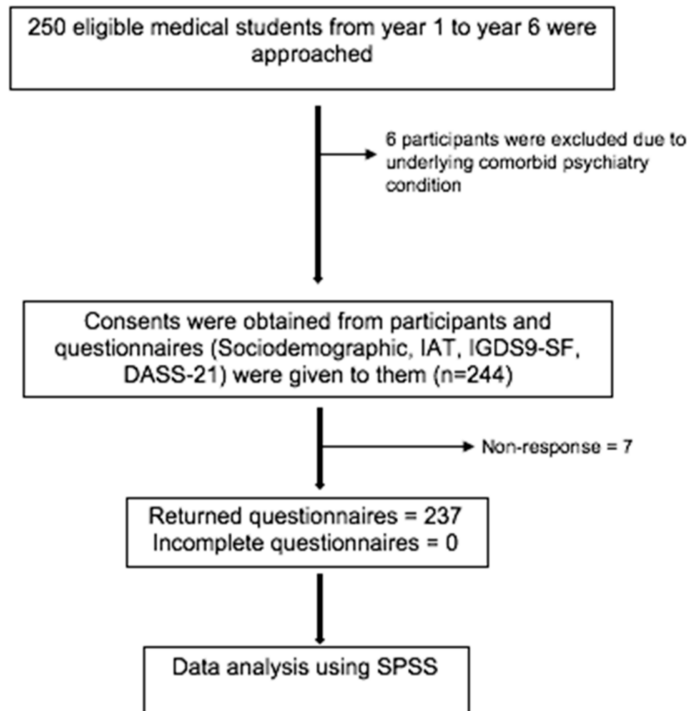

Figure 1. Flow chart of data collection.

\section{Data Analysis}

A descriptive analysis was conducted to determine the prevalence of IA and IGD as well as the sociodemographic characteristics of the study population, academic backgrounds and the internet use characteristics. The results were presented as frequency and percentage for categorical data and mean (standard deviation) for continuous data. A bivariate analysis was performed to establish the association between the following factors: gender, marital status, hometown, household income, internet use characteristics and academic years with (1) MVIAT and (2) Malay version of the IGDS9-SF. The level of significance was pre-set at 0.05 . The completed MVIAT and the Malay version of the IGDS9-SF were scored according to manual guidelines and literature reviews and all the scores were categorized into dichotomous groups. The bivariate analysis was also conducted between all the independent variables with the anxiety component in DASS-21 as the outcome. DASS-21 scores were categorized into dichotomous groups for a score of more than 7 for anxiety based on the descriptive cut-off score provided by the creator of the scale [29]. A bivariate analysis using Pearson Chi-square and Fisher's exact test was conducted to determine the association between the independent variables and the dependent variable. Significant bivariate analysis results were further analysed using a multiple logistic regression analysis. The collected data was analysed using the IBM SPSS (New York, NY, USA) statistical software program version 26. 


\section{Results}

The summaries of the participants' sociodemographic characteristics are described in Table 1 . The male participants represented $30.4 \%$ of the population. The age of the participants was not normally distributed where the z-value was 0.315 (skewness $0.143 / \mathrm{SE}$ $0.158)$ and Kolmogorov-Smirnov significant level was $<0.05(p \leq 0.001)$. The median age was 21.00 (3.0).

Table 1. Sociodemographic Profiles of Participants $(n=237)$.

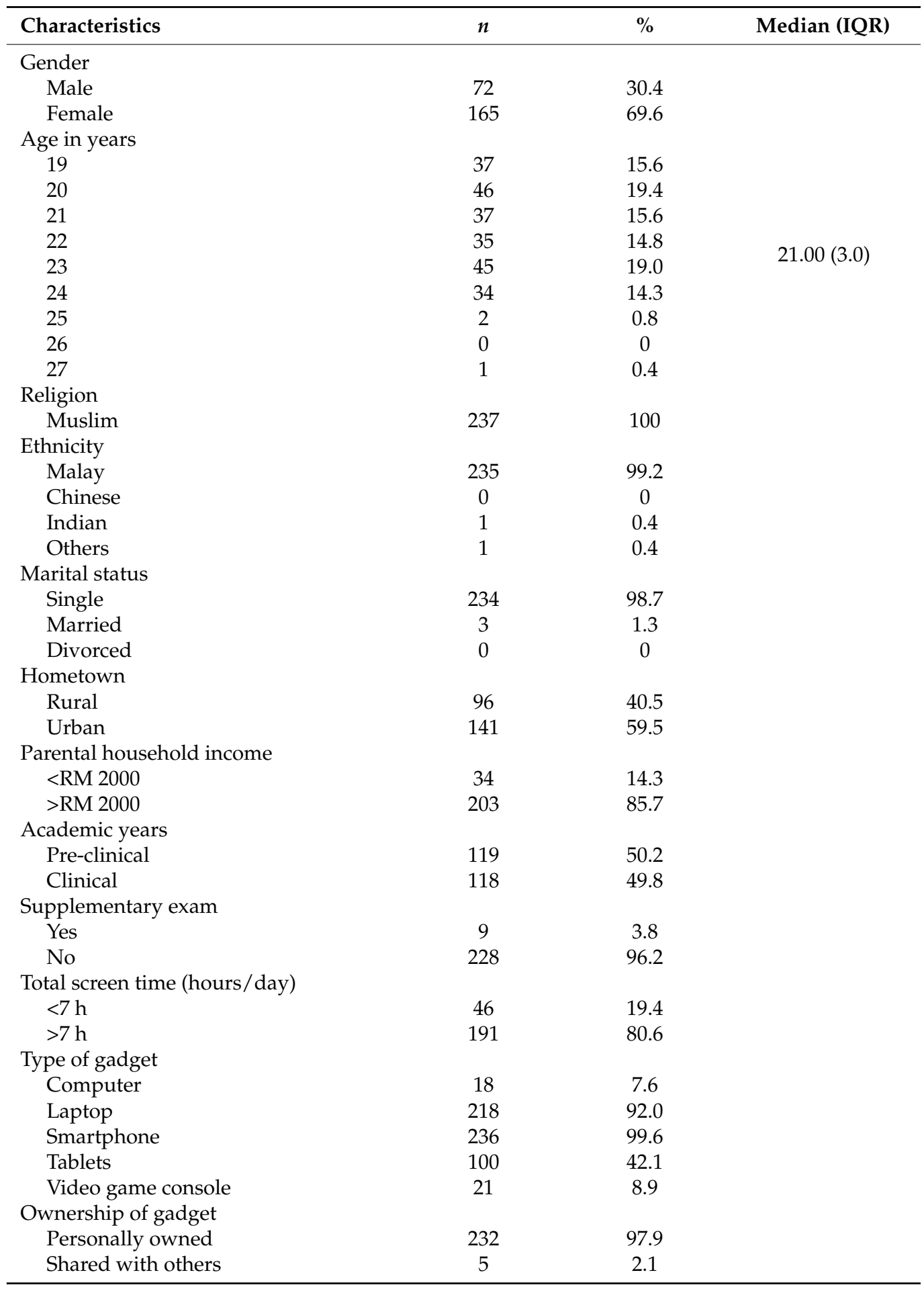


Table 1. Cont.

\begin{tabular}{|c|c|c|c|}
\hline Characteristics & $n$ & $\%$ & Median (IQR) \\
\hline \multicolumn{4}{|l|}{ Internet accessibility } \\
\hline At home & 237 & 100 & \\
\hline Library & 32 & 13.5 & \\
\hline Cybercafé & 7 & 3.0 & \\
\hline Hostel & 140 & 59.1 & \\
\hline Faculty & 125 & 52.7 & \\
\hline Public areas & 71 & 30.0 & \\
\hline \multicolumn{4}{|l|}{ Purpose(s) of using internet } \\
\hline Education & 57 & 24.1 & \\
\hline Social networking & 228 & 96.2 & \\
\hline Online gaming & 89 & 37.6 & \\
\hline Internet chatting & 234 & 98.7 & \\
\hline Online shopping & 187 & 78.9 & \\
\hline Blogs & 25 & 10.5 & \\
\hline Sexual activities & 3 & 1.3 & \\
\hline Surfing for leisure & 144 & 60.8 & \\
\hline Email & 160 & 67.5 & \\
\hline \multicolumn{4}{|l|}{ Social media ownership } \\
\hline Facebook & 200 & 84.4 & \\
\hline Twitter & 147 & 62.0 & \\
\hline Instagram & 217 & 91.6 & \\
\hline WhatsApp & 234 & 98.7 & \\
\hline YouTube & 190 & 80.2 & \\
\hline WeChat & 6 & 2.5 & \\
\hline Others & 56 & 23.6 & \\
\hline \multicolumn{4}{|l|}{ Video game genre } \\
\hline Not playing video game & 95 & 41.4 & \\
\hline MMORPG & 57 & 24.1 & \\
\hline Action/adventure & 35 & 14.8 & \\
\hline First-person shooter & 46 & 19.4 & \\
\hline Sports & 24 & 10.1 & \\
\hline Rhythm & 18 & 7.6 & \\
\hline Driving & 25 & 10.5 & \\
\hline Real time strategy & 48 & 10.2 & \\
\hline Puzzle & 58 & 24.5 & \\
\hline Board \& card games & 38 & 16.0 & \\
\hline Gambling & 5 & 2.1 & \\
\hline
\end{tabular}

Abbreviations: RM, Malaysian Ringgit; MMORPG, Massively Multiplayer Online Role-Playing Game.

Table 2 shows the association between sociodemographic characteristics, academic background, and internet use characteristics with anxiety. Among all of these, only academic years showed a significant association with anxiety whereby a greater number of those in pre-clinical years had anxiety compared to those in clinical years $\left(\chi^{2}=6.739 ; \mathrm{df}=1\right.$; $p=0.013)$. A Chi-square analysis revealed that IA was not significantly associated with $\operatorname{IGD}(p>0.05)$.

Table 3 shows the multiple logistic regression between the independent variables with anxiety. The model contained independent variables from which all the factors were statistically significant, $\chi^{2}(2, n=237)=18.62, p<0.001$, indicating that the model was able to differentiate between the respondents who reported and did not report being anxious. The strongest factor reported related to having anxiety was being in the pre-clinical years. The odds of having anxiety is 2.5 times more likely among pre-clinical years compared to clinical years, controlling for the other factors in this model [adjusted odds ratio $(\mathrm{AOR})=$ $2.489, p$-value $0.01,95 \% \mathrm{CI}=1.22-5.07]$. However, those with a greater IAT score had a lower anxiety level by $0.10(\mathrm{AOR}=0.100, p$-value $0.03,95 \% \mathrm{CI}=0.01-0.76)$, controlling for other factors in this model. 
Table 2. Association Between Sociodemographic Characteristics, Academic Background And Internet Use Characteristics With Anxiety $(n=237)$.

\begin{tabular}{|c|c|c|c|c|c|}
\hline \multirow[b]{2}{*}{ Variables } & \multicolumn{2}{|c|}{ Anxiety } & \multicolumn{3}{|c|}{ Test Statistics } \\
\hline & $\begin{array}{c}\text { No } \\
n(\%)\end{array}$ & $\begin{array}{c}\text { Yes } \\
n(\%)\end{array}$ & $x^{2}$ & df & $p$-Value \\
\hline \multicolumn{6}{|l|}{ Gender } \\
\hline Male & $60(83.3)$ & $12(16.7)$ & 0.497 & 1 & 0.593 \\
\hline Female & $131(79.4)$ & $34(20.6)$ & & & \\
\hline \multicolumn{6}{|l|}{ Marital Status } \\
\hline Single & $189(80.8)$ & $45(19.2)$ & $0.377^{a}$ & 1 & 0.478 \\
\hline Married & $2(66.7)$ & $1(33.3)$ & & & \\
\hline \multicolumn{6}{|l|}{ Hometown } \\
\hline Urban & $112(79.4)$ & $29(20.6)$ & 0.298 & 1 & 0.620 \\
\hline Rural & $79(82.3)$ & $17(17.7)$ & & & \\
\hline \multicolumn{6}{|l|}{ Parental household } \\
\hline $\begin{array}{l}\text { income } \\
\quad<\text { RM } 2000\end{array}$ & 31 (91.2) & $3(8.8)$ & $2.844^{\mathrm{a}}$ & 1 & 0.105 \\
\hline >RM 2000 & $160(78.8)$ & $43(21.2))$ & & & \\
\hline \multicolumn{6}{|l|}{ Academic years } \\
\hline Pre-clinical & $88(73.9)$ & $31(26.1)$ & 6.739 & 1 & 0.013 * \\
\hline Clinical & $103(87.3)$ & $15(12.7)$ & & & \\
\hline \multicolumn{6}{|l|}{ Supplementary exam } \\
\hline Yes & $7(77.8)$ & $2(22.2)$ & $0.047^{\mathrm{a}}$ & 1 & 0.688 \\
\hline No & $184(80.7)$ & $44(19.3)$ & & & \\
\hline \multicolumn{6}{|l|}{ Ownership of gadget } \\
\hline Personally owned & $187(80.6)$ & $45(19.4)$ & $0.001^{\mathrm{a}}$ & 1 & 1.000 \\
\hline Shared with others & $4(80.0)$ & $1(20.0)$ & & & \\
\hline \multicolumn{6}{|l|}{ Total screen time/day } \\
\hline$<7 \mathrm{~h}$ & $40(87.0)$ & $6(13.0)$ & 1.479 & 1 & 0.300 \\
\hline$>7 \mathrm{~h}$ & $151(79.1)$ & $40(20.9)$ & & & \\
\hline
\end{tabular}

Table 3. Multiple Logistic Regression Between Sociodemographic Characteristics, Academic Background And Internet Use Characteristics With Anxiety Among Medical Students.

\begin{tabular}{|c|c|c|c|}
\hline Factors & AOR & $95 \% \mathrm{CI}$ & $p$-Value \\
\hline \multicolumn{4}{|l|}{ Gender } \\
\hline Male & 1 & & \\
\hline Female & 0.775 & $0.35-1.71$ & 0.527 \\
\hline \multicolumn{4}{|l|}{ Marital } \\
\hline Single & 0.436 & $0.02-8.72$ & 0.587 \\
\hline Married & 1 & & \\
\hline \multicolumn{4}{|l|}{ Hometown } \\
\hline Urban & 1 & & \\
\hline Rural & 1.08 & $0.53-2.19$ & 0.830 \\
\hline \multicolumn{4}{|l|}{ Parental income } \\
\hline$<$ RM 2000 & 1 & & \\
\hline >RM 2000 & 0.479 & $0.14-1.70$ & 0.256 \\
\hline \multicolumn{4}{|l|}{ Academic years } \\
\hline Pre-clinical & 2.489 & $1.22-5.07$ & 0.012 * \\
\hline Clinical & 1 & & \\
\hline \multicolumn{4}{|c|}{ Supplementary exam } \\
\hline Yes & 1.422 & $0.23-8.72$ & 0.704 \\
\hline No & 1 & & \\
\hline \multicolumn{4}{|c|}{ Total screen time/day } \\
\hline$<7 \mathrm{~h}$ & 1 & & \\
\hline$>7 \mathrm{~h}$ & 0.553 & $0.21-1.44$ & 0.225 \\
\hline
\end{tabular}


Table 3. Cont.

\begin{tabular}{lccc}
\hline \multicolumn{1}{c}{ Factors } & AOR & $\mathbf{9 5 \% ~ C I ~}$ & $p$-Value \\
\hline $\begin{array}{l}\text { Ownership of the gadget } \\
\quad \text { Personally owned } \\
\text { Shared }\end{array}$ & 0.771 & $0.07-8.07$ & 0.828 \\
$\begin{array}{l}\text { Internet dependence } \\
\quad \text { Normal }\end{array}$ & 1 & & \\
$\quad$ IAT & 1 & & $0.026^{*}$ \\
IGDS9-SF & 0.100 & $0.01-0.76$ & \\
$\quad$ Non-Disorder & 1 & & 0.103 \\
$\quad$ Disordered & 0.240 & $0.04-1.33$ & \\
\hline $\begin{array}{l}\text { Note: * Significant at } p<0.05, \text { reference }=1, \text { Abbreviations: RM, Malaysian Ringgit; IGDS9-SF, Internet Gaming } \\
\text { Disorder Scale-Short Form. }\end{array}$
\end{tabular}

\section{Discussion}

This study revealed a drastic increase in the prevalence of IA, i.e., $83.5 \%$ among medical students during the pandemic compared to a pre-pandemic study, which reported its highest prevalence at 37\% [6]. Studies on IA across the world during the pandemic era are limited. Furthermore, there is a wide variation of its prevalence among countries. A recent study conducted in Indonesia revealed the prevalence of IA among adults was only $15 \%$, while in Nigeria, the prevalence was up to $55 \%$ among university students [30,31]. In another study, among the general population in Taiwan, the prevalence of IA was only $24.4 \%$ which was lower than the prevalence of this study [32,33]. The high prevalence of IA among medical students could be attributed to the COVID-19 pandemic itself. The current pandemic situation has prompted most people to spend more time in front of the computers or smartphones, maximizing their internet functions and benefits. This is particularly the case for students, as they were required to switch from the conventional learning environment to virtual platforms. In most cases, the switch had been swift and smooth since Malaysia's internet connectivity and accessibility are generally good [3].

The use of the internet via smartphone or computer has certainly increased during the pandemic. Because of the lack of physical outdoor activities in keeping with COVID19 restrictions, it has been utilised for a wide array of purposes besides being used for education, such as holding virtual workouts, doing online shopping and virtual socializing. Interactions with family members and friends were made safer and more convenient on the internet, and this served the purpose of complying with the restricted movement order to flatten the number of COVID-19 new cases [34]. However, the long-term effect of a prolonged and more frequent usage of the internet could predispose vulnerable individuals to IA [35].

For internet gaming, a meta-analysis study reported that the worldwide prevalence of IGD before the pandemic was 3.05\% [36]. A different meta-analysis study conducted across Southeast Asian countries revealed the pre-pandemic prevalence of IGD varied from $5.4 \%$ to $15.4 \%$ [37]. There is limited information on IGD locally during the pandemic period. A European study performed among the adult population during the pandemic showed that the prevalence of IGD was $29.6 \%$ [38], while a study in Japan discovered that there was 1.6 times increment of the prevalence, from $3.7 \%$ to $5.6 \%$ before and during pandemic [39]. In this study, we found that the prevalence of IGD was only $2.5 \%$, which is the lowest among other countries $[9,10,36,39]$. The discrepancies in the global prevalence could be the result of the non-uniform instrument tool used, the current pandemic situation, and different population samples [36,40]. A common explanation for the relatively high rate of IGD during this pandemic period is that internet gaming serves as a stress reliever to cope with pandemic anxiety and stress [41-44]. Nevertheless, our study did not find a high prevalence of IGD nor any significant association with anxiety among the medical students during the pandemic.

The prevalence of anxiety among the medical students in this study was $19.4 \%$. This finding was lower than those found in other studies worldwide, i.e., between $30-50 \%$, but 
comparable to the local prevalence of 22 to $30 \%$ [45-47]. This study found that those in preclinical years had a 2.5 times greater likelihood of developing anxiety than those in clinical years. Multiple factors played a role in inducing anxiety in both the pre-clinical and clinical years of a medical education. It may be due to the environmental factors (transitional phase from secondary school to tertiary education, adjustment to a new life, competitive environment), academic factors (excessive educational content, multiple examinations, expectation to master the knowledge) and personal factors (individual personality, parental expectation, fear of inadequacy) [47-49]. One plausible explanation is that those in the clinical years were still allowed to attend clinical sessions during CMCO; therefore, they experienced reduced social isolation which in turn lowered their anxiety level compared to those in pre-clinical years who had to have only online classes.

In stark contrast to the earlier pre-pandemic study findings that showed IA was linked to anxiety and other psychological impacts [46,50], this study reported those who scored as internet dependent were protected against anxiety. It is probable that excessive internet use served as a self-therapeutic method to escape from academic stress, and pandemic burn-out by reducing the feeling of social isolation, overcoming loneliness, having easy access to information and perhaps even providing a suitable medium for those with social anxiety to improve their social skills [51-53]. A further exploration regarding the motivation and purpose of the internet would be useful when examining the internet use among medical students to be more conclusive of how the internet could either be beneficial or harmful during stressful times such as the viral pandemic.

For internet gaming, other studies showed that IGD posed a significant association with psychological distress $[54,55]$. Even though internet gaming offers an easy way to escape from everyday life and potentially serves as a stress coping skill for negative emotions, there are definite factors that may protect people from being involved with too much internet gaming, in contrast to the internet use as shown in this study. These include the sociodemographic background of the students and individual factors (preference, personality), cognitive factors (IQ and perseverative errors), psychopathological conditions (underlying depression, anxiety and impulsivity), social interaction factors (family environment, social anxiety and self-esteem) as well as the nature of the study program itself [56-59].

Though the need for the usage of information and communication technology (ICT) is crucial during this difficult time and we could develop a dependence on it, its inherent risk can also be outweighed by its potential benefits. Nevertheless, caution must be undertaken for those who are vulnerable to developing overdependence [60]. Yet, at this point of time, it is difficult to limit the use of ICT. Therefore, it is very important for the university management to be able to detect problematic usage early to avoid potential future problems [61]. Preventive measures for both physical and mental health include: self-regulating screen time by limiting and balancing screen and internet time for important matters (education and searching information), preventing aimless browsing of the internet, establishing routine by turning off notifications during physical activities, enhancing and empowering physical activities either indoors or outdoors such as forest-bathing, strolling and jungle trekking (once permitted), managing stress sufficiently through a relaxation technique or spiritual technique, regular and adequate sleep, healthy eating and seeking help when needed [62-65].

\section{Conclusions}

In conclusion, this study showed that the prevalence of internet addiction during the pandemic was higher than the rates found during the pre-pandemic period. Nevertheless, the prevalence of internet gaming disorders remained as low as the rates reported prior to the pandemic. Medical students in the pre-clinical academic years were at a greater risk of anxiety while those who rated higher on the internet addiction scale were protected against anxiety. 


\section{Limitation}

This study had several limitations. Firstly, it used a cross-sectional study design whereby causal relationships could not be established. Secondly, the Malay version of IGDS9-SF used in this study had no locally validated cut-off point that would help to determine the proportion of those who needed a further clinical assessment for IGD. Lastly, the study population was homogenous from one university; all of whom were Malay Muslims and therefore would not represent all medical students in Malaysia. Nevertheless, its main strength is that, to the authors' knowledge, it is the first study to explore the relationship between internet use, online gaming and psychological wellbeing of medical students in consideration of the prominent use of the internet during the COVID-19 pandemic.

Author Contributions: Conceptualization, N.I. (Nurazah Ismail), A.B. and A.I.T.; data curation, N.I. (Nurazah Ismail); formal analysis, N.I. (Nurazah Ismail) and H.J.; methodology, N.I. (Nurazah Ismail), A.B.; project administration, N.I. (Nurazah Ismail); resources, N.I. (Nurazah Ismail); supervision, A.B., A.I.T.; writing—original draft, N.I. (Nurazah Ismail); writing—review and editing, A.B., A.I.T., H.J., N.R.N.J., N.I. (Normala Ibrahim) All authors have read and agreed to the published version of the manuscript.

Funding: This research received no external funding. The article processing charge was funded by Universiti Sains Islam Malaysia and Universiti Kebangsaan Malaysia.

Institutional Review Board Statement: The study was conducted according to the guidelines of the Declaration of Helsinki, and approved by the Ethics Committee of Universiti Kebangsaan Malaysia and Universiti Sains Islam Malaysia (protocol code JEP-2020-123, date of approval on 28 February 2020 and USIM/JKEP/2020-89, date of approval on 9 July 2020).

Informed Consent Statement: Informed consent was obtained from all subjects involved in the study.

Data Availability Statement: All the data are based on the current study analysis. The data presented in this study are available on request from the corresponding author.

Acknowledgments: We would like to thank all participants at Universiti Sains Islam Malaysia. We would also like to extend our appreciation to all authors for granting us permission to use their questionnaires.

Conflicts of Interest: The authors declare no conflict of interest.

\section{References}

1. Prime Minister Office of Malaysia. Teks Ucapan Perkembangan Terkini Perintah Kawalan Pergerakan Pemulihan (PKPP). Available online: https://www.bharian.com.my/berita/nasional/2021/01/775155/kronologi-pelaksanaan-fasa-pkp (accessed on 12 January 2021).

2. Standard Operating Procedure by National Security Council). Available online: https://asset.mkn.gov.my/web/wp-content/ uploads/sites/3/2021/01/SOP-PKPB-Semenanjung-Malaysia-kecuali-Perlis-Pahang-dan-Kelantan-kemaskini-14-November2020.pdf (accessed on 7 October 2021).

3. Malaysian Communications and Multimedia Commission (MCMC). 2020. Internet Users Survey. Malaysian Communications and Multimedia Commission 9-25. Available online: https://www.mcmc.gov.my/skmmgovmy/media/General/pdf/IUS-2020 -Report.pdf (accessed on 12 January 2021).

4. World Health Organization. Public Health Implications of Excessive Use of the Internet, Computers, Smartphones and Similar Electronic Devices: Meeting Report; World Health Organization: Tokyo, Japan, 2014; pp. 1-151.

5. Cheng, C.; Li, A.Y.-L. Internet Addiction Prevalence and Quality of (Real) Life: A Meta-Analysis of 31 Nations Across Seven World Regions. Cyberpsychol. Behav. Soc. Netw. 2014, 17, 755-760. [CrossRef]

6. Ching, S.M.; Hamidin, A.; Vasudevan, R.; Sazlyna, M.S.L.; Aliaa, W.S.W.; Foo, Y.L.; Yee, A.; Hoo, F.K. Prevalence and factors associated with internet addiction among medical students-A cross-sectional study in Malaysia. Med. J. Malays. 2017, 72, 7-11.

7. Haque, M.; Rahman, N.A.; Majumder, M.A.; Haque, S.Z.; Kamal, Z.M.; Islam, Z.; Haque, A.E.; Rahman, N.I.A.; Alattraqchi, A.G. Internet use and addiction among medical students of Universiti Sultan Zainal Abidin, Malaysia. Psychol. Res. Behav. Manag. 2016, 14, 297-307. [CrossRef] [PubMed]

8. Zhang, M.W.B.; Lim, R.B.C.; Lee, C.; Ho, R.C.M. Prevalence of Internet Addiction in Medical Students: A Meta-analysis. Acad. Psychiatry 2017, 42, 88-93. [CrossRef] [PubMed]

9. Mihara, S.; Higuchi, S. Cross-sectional and longitudinal epidemiological studies of Internet gaming disorder: A systematic review of the literature. Psychiatry Clin. Neurosci. 2017, 71, 425-444. [CrossRef] 
10. Mak, K.-K.; Lai, C.-M.; Watanabe, H.; Kim, D.-I.; Bahar, N.; Ramos, M.; Young, K.S.; Ho, R.C.M.; Aum, N.-R.; Cheng, C. Epidemiology of Internet Behaviors and Addiction Among Adolescents in Six Asian Countries. Cyberpsychol. Behav. Soc. Netw. 2014, 17, 720-728. [CrossRef] [PubMed]

11. Nik Jaafar, N.R.; Baharudin, A.; Tajjudin, I.; Ling, S.L.; Safarudin, M.A.; Sufia, D.S.; Tan, Y.H.; Zulkifle, N.H.; Tan, K.-A. Factors correlated with internet gaming disorder among Malaysian University students. Malays. J. Med. Health Sci. 2021, 17, 54-62.

12. Chaudhari, B.; Menon, P.; Saldanha, D.; Tewari, A.; Bhattacharya, L. Internet addiction and its determinants among medical students. Ind. Psychiatry J. 2015, 24, 158-162. [CrossRef]

13. Carvalho, P.M.D.M.; Moreira, M.M.; de Oliveira, M.N.A.; Landim, J.M.M.; Neto, M.L.R. The psychiatric impact of the novel coronavirus outbreak. Psychiatry Res. 2020, 286, 112902. [CrossRef]

14. Shanmugam, H.; Juhari, J.A.; Nair, P.; Chow, S.K.; Ng, C.G. Impacts of COVID-19 pandemic on mental health in Malaysia: A single thread of hope. Malays. J. Psychiatry Ejournal 2020, 29, 78-84.

15. Xiang, Y.-T.; Yang, Y.; Li, W.; Zhang, L.; Zhang, Q.; Cheung, T.; Ng, C.H. Timely mental health care for the 2019 novel coronavirus outbreak is urgently needed. Lancet Psychiatry 2020, 7, 228-229. [CrossRef]

16. CDC. Post-Covid Conditions. 2021. Available online: https://www.cdc.gov/coronavirus/2019-ncov/long-term-effects.html\# print (accessed on 1 May 2021).

17. Mohd Salleh, H.; Azman, N.; Nik Jaafar, N.R.; Mohd Daud, T.I.; Baharudin, A.; Ismail, A.K.; Abdul Malek, A.Z.; Hassan, M.R.; Mohammed Nawi, A. Health Anxiety and Its Correlations with Self-Perceived Risk and Attitude on COVID-19 among Malaysian Healthcare Workers during the Pandemic. Int. J. Environ. Res. Public Health 2021, 18, 4879. [CrossRef] [PubMed]

18. Woon, L.S.-C.; Sidi, H.; Nik Jaafar, N.R.; Abdullah, M.F.I.L. Mental Health Status of University Healthcare Workers during the COVID-19 Pandemic: A Post-Movement Lockdown Assessment. Int. J. Environ. Res. Public Health 2020, 17, 9155. [CrossRef]

19. Kobbin, V.; Jzui, N.W.; Teo, M.; Ting, X.H.; Abdul Halim, I.A. Fear, anxiety and coping mechanism during COVID-19 pandemic among undergraduates. Int. J. Biomed. Clin. Sci. 2020, 5, 217-228.

20. Khodabakhsh, S.; Ramasamy, S.; Teng, T.Y.; Leng, C.S. Impact of Internet Addiction on Health Anxiety in Malaysian Youth During Covid-19 Pandemic. Malays. J. Med Res. 2021, 5, 12-18. [CrossRef]

21. Naing, L.; Winn, T.; Rusli, B. Practical issues in calculating the sample size for prevalence studies. Arch. Orofac. Sci. 2006, 1, 9-14.

22. Frangos, C.C.; Frangos, C.C.; Sotiropoulos, I. A meta-analysis of the reliabilty of young's internet addiction test. Proc. World Congr. Eng. 2012, 1, 368-371.

23. Ng, C.G.; Mohammed Isa, S.; Hashim, A.H.; Pillai, S.K.; Singh, M.K.H. Validity of the Malay version of the Internet Addiction Test: A study on a group of medical students in Malaysia. Asia Pacific J. Public Health 2015, 27, NP2210-NP2219.

24. Widyanto, L.; Mcmurran, M. The Psychometric Properties of the Internet Addiction Test. Cyberpsychol. Behav. 2004, 7, 443-450. [CrossRef]

25. American Psychiatric Association. Diagnostic and statistical manual of mental disorders. BMC Med. 2013, 17, $133-137$.

26. Pontes, H.M.; Griffiths, M. Measuring DSM-5 internet gaming disorder: Development and validation of a short psychometric scale. Comput. Hum. Behav. 2015, 45, 137-143. [CrossRef]

27. Qin, L.; Cheng, L.; Hu, M.; Liu, Q.; Tong, J.; Hao, W.; Luo, T.; Liao, Y. Clarification of the Cut-off Score for Nine-Item Internet Gaming Disorder Scale-Short Form (IGDS9-SF) in a Chinese Context. Front. Psychiatry 2020, 11, 470. [CrossRef] [PubMed]

28. Ling, S.; Jaafar, N.N.; Tan, K.-A.; Bahar, N.; Baharudin, A.; Tajjudin, A.A. Psychometric Properties of the Malay Version of the Internet Gaming Disorder Scale-Short Form (IGDS9-SF-M): Evidence from a Sample of Malaysian Undergraduates. Int. J. Environ. Res. Public Health 2021, 18, 2592. [CrossRef] [PubMed]

29. Musa, R.; Fadzil, M.A.; Zain, Z. Translation, validation and psychometric properties of Bahasa Malaysia version of the Depression Anxiety and Stress Scales (DASS). ASEAN J. Psychiatry 2007, 8, 82-89.

30. Olawade, D.B.; Olorunfemi, O.J.; Wada, O.Z.; Afolalu, T.D.; Enahoro, M.A. Internet Addiction among University Students during Covid-19 Lockdown: Case Study of Institutions in Nigeria. J. Educ. Hum. Dev. 2020, 9. [CrossRef]

31. Siste, K.; Hanafi, E.; Sen, L.T.; Christian, H.; Adrian, A.; Siswidiani, L.P.; Limawan, A.P.; Murtani, B.J.; Suwartono, C. The Impact of Physical Distancing and Associated Factors Towards Internet Addiction Among Adults in Indonesia During COVID-19 Pandemic: A Nationwide Web-Based Study. Front. Psychiatry 2020, 11. [CrossRef]

32. Jovic, J.; Pantovic-Stefanovic, M.; Mitkovic-Voncina, M.; Dunjic-Kostic, B.; Mihajlovic, G.; Milovanovic, S.; Ivkovic, M.; Fiorillo, A.; Latas, M. Internet use during coronavirus disease of 2019 pandemic: Psychiatric history and sociodemographics as predictors. Indian J. Psychiatry 2020, 62, 383-S390. [CrossRef] [PubMed]

33. Lin, M.-P. Prevalence of Internet Addiction during the COVID-19 Outbreak and Its Risk Factors among Junior High School Students in Taiwan. Int. J. Environ. Res. Public Health 2020, 17, 8547. [CrossRef]

34. Lan, H.T.Q.; Long, N.T.; Van Hanh, N. Validation of depression, anxiety and stress scales (DASS-21): Immediate psychological responses of students in the e-learning environment. Int. J. High. Educ. 2020, 9, 125. [CrossRef]

35. Siomos, K.E.; Dafouli, E.D.; Braimiotis, D.A.; Mouzas, O.D.; Angelopoulos, N.V. Internet Addiction among Greek Adolescent Students. Cyberpsychol. Behav. 2008, 11, 653-657. [CrossRef]

36. Stevens, M.W.; Dorstyn, D.; Delfabbro, P.H.; King, D.L. Global prevalence of gaming disorder: A systematic review and meta-analysis. Aust. N. Z. J. Psychiatry 2020, 55, 553-568. [CrossRef] [PubMed] 
37. Chia, D.X.Y.; Ng, C.W.L.; Kandasami, G.; Seow, M.Y.L.; Choo, C.C.; Chew, P.K.H.; Lee, C.; Zhang, A.M.W. Prevalence of Internet Addiction and Gaming Disorders in Southeast Asia: A Meta-Analysis. Int. J. Environ. Res. Public Health 2020, 17, 2582. [CrossRef]

38. Concerto, C.; Rodolico, A.; Avanzato, C.; Fusar-Poli, L.; Signorelli, M.S.; Battaglia, F.; Aguglia, E. Autistic traits and attentiondeficit hyperactivity disorder symptoms predict the severity of internet gaming disorder in an italian adult population. Brain Sci. 2021, 11, 6. [CrossRef] [PubMed]

39. Oka, T.; Hamamura, T.; Miyake, Y.; Kobayashi, N.; Honjo, M.; Kawato, M.; Kubo, T.; Chiba, T. Prevalence and risk factors of internet gaming disorder and problematic internet use before and during the COVID-19 pandemic: A large online survey of Japanese adults. J. Psychiatr. Res. 2021, 142, 218-225. [CrossRef]

40. King, D.L.; Chamberlain, S.R.; Carragher, N.; Billieux, J.; Stein, D.; Mueller, K.; Potenza, M.N.; Rumpf, H.J.; Saunders, J.; Starcevic, V.; et al. Screening and assessment tools for gaming disorder: A comprehensive systematic review. Clin. Psychol. Rev. 2020, 77, 101831. [CrossRef] [PubMed]

41. Billieux, J.; Flayelle, M.; Rumpf, H.-J.; Stein, D.J. High Involvement Versus Pathological Involvement in Video Games: A Crucial Distinction for Ensuring the Validity and Utility of Gaming Disorder. Curr. Addict. Rep. 2019, 6, 323-330. [CrossRef]

42. Carras, M.C.; Rooij, A.J.V.; de Mheen, D.V.; Musci, R.; Xue, Q.; Mendelson, T. Video gaming in a hyperconnected world: A cross-sectional study of heavy gaming, problematic gaming symptoms, and online socializing in adolescents. Comput. Hum. Behav. 2017, 68, 472-479. [CrossRef]

43. King, D.L.; Delfabbro, P.H.; Billieux, J.; Potenza, M.N. Problematic online gaming and the COVID-19 pandemic. J. Behav. Addict. 2020, 9, 184-186. [CrossRef] [PubMed]

44. Russoniello, C.; O'Brien, K.; Parks, J.M. The effectiveness of casual video games in improving mood and decreasing stress. J. Cyber Ther. Rehabil. 2009, 2, 53-66.

45. Bayram, N.; Bilgel, N. The prevalence and socio-demographic correlations of depression, anxiety and stress among a group of university students. Soc. Psychiatry Psychiatr. Epidemiol. 2008, 43, 667-672. [CrossRef]

46. Dahlin, M.; Joneborg, N.; Runeson, B. Stress and depression among medical students: A cross-sectional study. Med. Educ. 2005, 39, 594-604. [CrossRef] [PubMed]

47. Yusoff, M.S.B.; Yee, L.Y.; Wei, L.H.; Meng, L.H.; Bin, L.X.; Siong, T.C.; Rahim, A.F.A. A study on stress, stressors and coping strategies among Malaysian medical students. Int. J. Stud. Res. 2011, 1, 45-50. [CrossRef]

48. Abdallah, A.R.; Gabr, H.M. Depression, anxiety and stress among first year medical students in an Egyptian public university. Int. Res. J. Med. Med. Sci. 2014, 2, 11-19.

49. Sherina, M.S.; Rampal, L.; Kaneson, N. Psychological stress among undergraduate medical students. Med. J. Malays. 2004, 59, 207-211.

50. Azher, M.; Khan, R.B.; Salim, M.; Bilal, M.; Hussain, A.; Haseeb, M. The relationship between internet addiction and anxiety among students of University of Sargodha. Int. J. Humanit. Soc. Sci. 2014, 4, 288-293.

51. Jun, S.; Choi, E. Academic stress and Internet addiction from general strain theory framework. Comput. Hum. Behav. 2015, 49, 282-287. [CrossRef]

52. Lan, N.T.M.; Kyesun, L.; Dung, V.; Huyen, N.T.T.; van Chan, H.; Quy, N.T.; Huong, T.T.; Mai, N.T.H.; Trang, V.T.; van Hieu, N. Internet addiction among university students and its associated factors: A cross-sectional study among college students in Hanoi, Vietnam. Syst. Rev. Pharm. 2020, 11, 590-596.

53. Morahan-Martin, J. The Relationship Between Loneliness and Internet Use and Abuse. Cyberpsychol. Behav. 1999, 2, 431-439. [CrossRef]

54. Fernandes, B.; Biswas, U.N.; Tan-Mansukhani, R.; Vallejo, A.; Essau, C.A. The impact of COVID-19 lockdown on internet use and escapism in adolescents. Rev. Psicol. Clin. Con Niños Adolesc. 2020, 7, 59-65.

55. Wong, H.Y.; Mo, H.Y.; Potenza, M.N.; Chan, M.N.M.; Lau, W.M.; Chui, T.K.; Pakpour, A.H.; Lin, C. Relationships between severity of internet gaming disorder, severity of problematic social media use, sleep quality and psychological distress. Int. J. Environ. Res. Public Health 2020, 17, 1879. [CrossRef]

56. Han, D.H.; Lee, Y.S.; Yang, K.C.; Kim, E.Y.; Lyoo, I.K.; Renshaw, P.F. Dopamine Genes and Reward Dependence in Adolescents with Excessive Internet Video Game Play. J. Addict. Med. 2007, 1, 133-138. [CrossRef]

57. Hyun, G.J.; Han, D.H.; Lee, Y.S.; Kang, K.D.; Yoo, S.K.; Chung, U.-S.; Renshaw, P.F. Risk factors associated with online game addiction: A hierarchical model. Comput. Hum. Behav. 2015, 48, 706-713. [CrossRef]

58. King, D.L.; Delfabbro, P.H. The cognitive psychology of Internet gaming disorder. Clin. Psychol. Rev. 2014, 34, 298-308. [CrossRef] [PubMed]

59. Leménager, T.; Gwozd, A.; Ritcher, A.; Reinhard, I.; Kämmerer, N.; Sell, M.; Mann, K. Self-concept deficits in massively multiplayer online role-playing games addiction. Eur. Addict. Res. 2013, 19, 227-234. [CrossRef] [PubMed]

60. WHO. Healthyathome-Mental-Health. Available online: www.Who.Int (accessed on 26 February 2021).

61. Capetillo-Ventura, N.; Juárez-Treviño, M. Internet addiction in university medical students. Med. Univ. 2015, 17, 88-93. [CrossRef]

62. Amin, K.P.; Griffiths, M.D.; Dsouza, D.D. Online Gaming During the COVID-19 Pandemic in India: Strategies for Work-Life Balance. Int. J. Ment. Health Addict. 2020, 17, 1-7. [CrossRef]

63. Király, O.; Potenza, M.N.; Stein, D.J.; King, D.L.; Hodgins, D.C.; Saunders, J.B.; Griffiths, M.D.; Gjoneska, B.; Billieux, J.; Brand, M.; et al. Preventing problematic internet use during the COVID-19 pandemic: Consensus guidance. Compr. Psychiatry 2020, 100, 152180. [CrossRef] 
64. Farrow, M.R.; Washburn, K.A. Review of Field Experiments on the Effect of Forest Bathing on Anxiety and Heart Rate Variability. Glob. Adv. Health Med. 2019, 8, 1-7. [CrossRef] [PubMed]

65. Roviello, V.; Roviello, G.N. Less COVID-19 Deaths in Southern and Insular Italy Explained by Forest Bathing, Mediterranean Environment, and Antiviral Plant Volatile Organic Compounds. Environ. Chem. Lett. 2021, 1, 1-11. [CrossRef] 